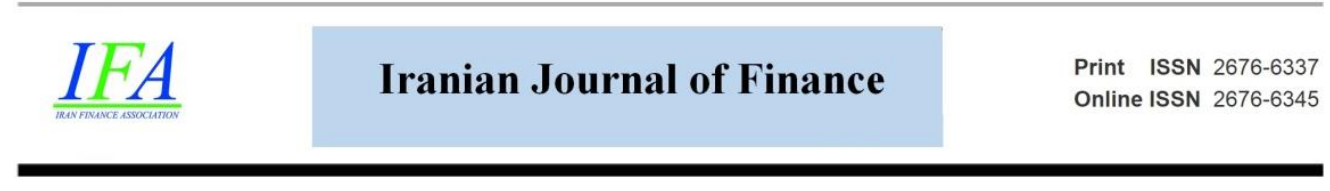

\title{
The Event Research in the Effect of Clear Rumor Declarations on Abnormal Stock Returns Behavior
}

\section{Javid Hatam}

Department of Accounting, Aliabad Katoul Branch, Islamic Azad University, Aliabad Katoul, Iran. (Email: javidhatam@gmail.com)

\section{Maryam Bokharaeian Khorasani*}

*Corresponding Author, Department of Accounting, Aliabad Katoul Branch, Islamic Azad University, Aliabad Katoul, Iran. (Email: maryam.bokhara@gmail.com)

\section{Arash Naderian}

Department of Accounting, Aliabad Katoul Branch, Islamic Azad University, Aliabad Katoul, Iran. (Email: naderian@aliabadiau.ac.ir)

\section{Jamadori Gorganli Doji}

Department of Accounting, Aliabad Katoul Branch, Islamic Azad University, Aliabad Katoul, Iran. (Email: gorganli@ aliabadiau.ac.ir)

Document Type: Original Article

Received: 2020/11/15
2021, Vol. 5, No. 3. 17-37.

Published: 2021/07/03

\begin{abstract}
In this research, the impact of clear rumor declarations on the measurement of abnormal stock returns behavior has been investigated in Tehran Stock Market by means of event research so that to reveal well abnormal stock returns behavior. Following testing 169 clear rumor declarations during the period (2017-2019), Using Spss statistical software version 26 and Eviews version 12, the results of regression analysis and correlation tests indicate that content of clear rumor declarations may affect abnormal stock returns behavior. Confirmation of good rumors has increased the efficiency of abnormal stock returns 10 days after the date of the given declaration and approval of bad rumors has led to reducing the efficiency of abnormal stock returns upon declaration day. Similarly, the results showed that if rumors were disclosed
\end{abstract}


during working hours in Tehran Stock Market they would reduce the efficiency of abnormal stock returns on the same day. After comparing the results of the research, the need to educate and promote the shareholding culture among shareholders is felt more than ever before. They also need to shift their focus from focusing on rumors to principled investing in futures stocks to avoid cross-sectional fluctuations, destructive rumors and other market risks and achieve a good return stock.

Keywords: Rumors, Abnormal return, Event research, Disclosure declarations

DOI: 10.30699/IJF.2021.256891.1173

Publisher: Iran Finance Association Copyright: author(s)

Type of License: Creative Commons License (CC-BY 4.0)

\section{Introduction}

In the stock market, people invest in two types of information; one is the basic information of a company and the other is the rumor. Having few ideas about the stock market, a significant percentage of the population usually do investments on the basis of rumor (Mohammad A \& et al. 2018). During the recent years it's been observed over and over that the shares' values have been faced with fluctuations merely based on market news and rumors; the news that lacked even the least basic vision, and mostly changed with a slight excitement; furthermore, the attraction of controlling fluctuations and shortterm insights to investing are all factors that intensify the effect of rumors on the exchange. Rumors have never ceased in the stock market; thus they usually cause great problems for the market investors and controllers (Jun Wang \& et al. 2017). It's clear that the non-logical increase of share price under the effect of rumors would cause that the share price goes beyond the actual price and thus it leads to the unfair loss of some stockholders and the unfair benefit of some others. When rumors get to the abnormal activity in the market, the best possible way for supporting market unity would be information discloser done by the Ltd to the extent that rumors are ceased. On such occasions, the on-time reaction of stock exchange distributers to rumors would cause the inattention of investors to rumors (Rahpeik and Shamsollahi 2017). As a result, researches over rumors and limiting them in the financial markets have been increasingly considered by researchers.

\section{Clear rumor declarations}

Actually, rumor has turned into a big threat and an important unstable factor affecting share markets. In the stock exchange rumors seriously fade away the 
information transparency. Thus, rumor as an important danger source has been considered for share markets. In terms of theory, the information transparency increased by rumor lead to the share market stabilization (Jun Wang et al. 2017). Response disclosure shall contain information that approves rumor in case that the rumor is true, and denies the rumor in case that's untrue. The main purpose of this policy is to increase price efficiency and to warn investors about the possibility of information asymmetry. Disclosure of Inquiry warns traders to get aware of rumors and alarm some forces to dissolve this asymmetry in a short time; nevertheless, this attention makes unaware traders trade more and thus gain more profit for the aware traders (Guilbert, 2016). On the contrary rumor clarification by market participants has not been well accepted by some researchers. They believe rumor clarification in social media provides a second chance for the rumor to spread, and they could increase abnormal stock returns. In terms of theory, the information clarification increased by rumors would cause the decrease of stock markets abnormal return and the increase of market returns (Jun Wang \& et al).

\section{Clear rumor declarations and their position}

The rumors of listed companies caused abnormal volatility in stock prices (Lim and Kong, 2004), increased the operating risk of listed companies (Kiymaz, 2002), and had a certain impact on the stability of the securities market (Peinan, J \& et al., 2020). By perceiving the detrimental impacts of rumors in security and exchange markets, the governments from various countries e.g. China and the US have so far considered two solutions for the problem of reducing the negative and destructive effects of rumors in the long run: 1) Blocking rumors in the most influential users or panels of society; 2) spreading facts to clarify rumors (Wen et al., 2014, quoted from Peinan, J \& et al., 2020:5). Concerning their considerations and environments, both methods claim for better results; nevertheless, for many enterprises, publishing of clear rumor declaration is deemed as the easiest and fastest technique (Peinan, $\mathrm{J} \&$ et al., 2020:6). Whereas rumors could not be erased from the markets totally thus some governments have published certain rules and required the listed enterprises to clarify the misleading reports and effect in the main media. Transparency of information by disclosure of rumors via reduced difference among investors may increase stability in the stock markets. Furthermore, given publisher's obligation is not unrestricted for correction of rumors and to some cases in which the rumors may affect the decision made by investors and price of bond and securities. With respect to Clause 4 of Article 45 of Act of IRI Tehran Stock Market, the publisher's pledge has been accepted for disclosure of all information that may significantly affect the price of securities 
and investors' decision and therefore it can be implied that the publisher will be required for correction of the rumors spread in Tehran Stock Market. If the publisher violates the execution of that obligation, Tehran Stock Market will disclose non-responding and the publisher will be liable for compensation of any loss incurred by third parties versus this measure. As mentioned in Article 14 in which the performance instruction for disclosure of information of listed enterprise in Tehran Stock Market (approved in 2007) and in the execution of Clauses 11 and 18 of Article 7 and Article 45 of IRI Stock Market Act that has been approved by the board of directors of Tehran Stock Market if it was held 'In the event of spreading rumor or report that includes false or misleading information or fake documents, the publisher shall immediately send the adequate information and notes concerning the given rumor or related report to Tehran Stock Market and disclose it for public information.' In the conducted amendments in this instruction in Article 6 of this instruction, it was held that publisher will be required for disambiguation regarding rumors: 'The publisher will be responsible for disclosure of any case of rumors. In the case of publishing any rumor, or news or report by official media for disclosure of information by the listed enterprises in Tehran Stock Market if it was not informed to the public, the publisher managers shall immediately disclose the given rumor or report by the presentation of disambiguation report and adequate information and notes after being informed or by the request from Tehran Stock Market or related organization.' Therefore, the publisher shall be pledged for disambiguation of rumors and if breaches this obligation, according to the provision of this article, 'in the case of non-presentation of the report for transparency by the publisher, the organization will disclose nonresponding.' Similarly, according to Article 25 of this instruction: 'According to the sixth chapter of Tehran Stock Market Act and disciplinary regulations, thus separate investigation will be conducted on rumors about time and the perceived effect of given disclosure.' (Rahpeik \& Shmasollahi, 2018).

\section{Research Background}

In a survey by extraction of 4.134 pairs of rumors spread by 687.429 posts in social media and using event research method, Wang, Jun et al. (2017) concluded that the rumors spread by messages might affect abnormal stock returns and this might be measured by opposite excitation from spreading rumors while corporate online behaviors could not influence in this abnormal return, except total numbers of answers to the spread rumors for the recorder enterprise. 
Using an event research study, Peinan J. et al. (2020) explored the effects of rumor and formal rumor disambiguation on Chinese stock returns under various circumstances. The given results are extracted from 832 clear rumor declarations in Chinese enterprises within a time interval (2015-2017). The results show that the cumulative mean of abnormal returns after rumor event is noticeably positive in positive and neutral rumor samples and it is remarkably negative in negative rumor sample. Researchers assumed declarations as effective for positive and negative rumor samples after clear rumor declarations but considered them as neutral for the negative samples. Nonetheless, by comparing rumor declarations at various times they concluded that the earlier these rumors were disambiguated by enterprises, the lesser impact would be exerted both in positive and negative rumor samples.

By extraction of 12,663 pairs of rumor declarations from 1,840,520 posts in social media and by using analysis of emotions along with corporate online behaviors, Qianwei Y. et al. (2019) concluded that transparency of digital rumor might affect abnormal returns and it could be explained by emotions; alternately, the online transparent behaviors of enterprises included frequency of information disclosure and time of response and expression and they would not be limited to the effect on abnormal stock returns.

By extraction of 4,134 transparency pairs out of 687,429 posts sent to social media and employing event research technique, Jun W et al. (2017) analyzed the impact of transparency on stock return. Their findings suggest that the clarified messages have not been well accepted in social media by actors in Exchange Market and this may provide a second chance for spreading rumor and it may increase abnormal stock returns further.

In event research and by considering the day of clear rumor declaration as an event day and through analysis on 30 commercial and public enterprises in Shanghai and Shenzhen Exchange Markets for disclaimer of rumors from 1es October 2006 through $30^{\text {th }}$ October 2007, when they issued transparency declarations, Xiaolan Y. and Jianfang Z. (2016) concluded that transparency of rumors might be followed with noticeable returns 20 days before and after rumor disambiguation. The cumulative abnormal return is high up to $60.18 \%$ in a day before clear rumor declaration and cumulative abnormal return will decrease after transparency declaration, but the cumulative abnormal return may increase gradually $27.5 \%$ for 20 subsequent days. No study is observed to be conducted during the years 2013-2016.

However using the event research method, Zhang N. and Liu C.L. (2012) analyzed the effectiveness of reforms in clear rumor declarations and found 
that accurate transparency information might contribute to reducing the effect of rumors while the stock price might tend to return to normal level after 30 contractual days. Bashkirk (2012) found that re-disclosure of rumors could increase the speed of submission of price information. Similarly, Zhao et al. (2010) found that stability of stock price might be difficult after issuance of clear rumor declaration. Also in another study, Marshall et al. (2009) expressed that stock price might go back to the original level after clarifying the related rumors within 5 days.

First group hypothesis: The content of rumors may affect abnormal stock return in the event research.

Second group hypothesis: Issuance of transparency declaration based on confirmation of good rumors impacts on abnormal stock return in the event research.

Third group hypothesis: Issuance of transparency declaration based on confirmation of bad rumors influences in abnormal stock returns in the event research.

Fourth group hypothesis: time of transparency declaration affects stock return in the event research.

\section{Methodology}

The method of this study is descriptive of correlation type and since historical information is used therefore it of ad hoc type and within the field of proved accounting studies. The statistical population of the current study includes all listed enterprises in Tehran Stock Market. The sample size comprises enterprises, which issued clear rumor declarations in response to the rumors spread in cyberspace and various Tehran Stock Market websites concerning them or relevant group in Publishers' Data Analysis System (TEDAN) and Publishers' Comprehensive Communication System (CODAL) in Tehran Stock Market. Therefore, the group of our data is composed of transparent data and from stock contract data of this type of enterprises. Clear rumor declarations are prepared according to transparency declaration about the rumor, news or report published in Publishers' Data Analysis System (TEDAN) and Publishers' Comprehensive Communication System (CODAL) in Tehran Stock Market where they published transparency declarations from 12/02/2018 through 16/03/2020. 
Table 1. Process of screening of clear rumor declarations as members in the sample within the research time interval

\begin{tabular}{|l|c|}
\hline Description & Quantity \\
\hline The existing declarations in CODAL site & 261 \\
\hline Unusable fields & 58 \\
\hline Disclosure of proper and improper rumors at the same time & 12 \\
\hline $\begin{array}{l}\text { Disclosure of a rumor for more than one time in less than 7 } \\
\text { transactional day }\end{array}$ & 22 \\
\hline Total number of deleted declarations & 92 \\
\hline Number of studied declarations & 169 \\
\hline
\end{tabular}

Table 2. Summarized statistics of a group of data for clear rumor declarations in TEDAN system and CODAL site

\begin{tabular}{|c|c|c|}
\hline \multicolumn{2}{|l|}{ Characteristics } & $\begin{array}{c}\text { Sum/ } \\
\text { percentage }\end{array}$ \\
\hline \multirow[t]{3}{*}{ Type of rumors } & Good & 0.79 \\
\hline & Neutral with bad explanations & 0.02 \\
\hline & $\mathrm{Bad}$ & 0.19 \\
\hline Disclosure rumor words & The average number of words & 110 \\
\hline $\begin{array}{ll}\text { Disclosure } & \text { rumor } \\
\text { characters } & \end{array}$ & The average number of characters & 573 \\
\hline \multirow[t]{2}{*}{ Disclosure hours } & Within working hours & 0.36 \\
\hline & Out of working hours & 0.64 \\
\hline \multirow{3}{*}{$\begin{array}{l}\text { Clear positive rumor } \\
\text { declaration }\end{array}$} & Confirmed & 0.38 \\
\hline & Will be informed & 0.05 \\
\hline & Disclaimed & 0.36 \\
\hline \multirow{3}{*}{$\begin{array}{l}\text { Clear negative rumor } \\
\text { declaration }\end{array}$} & Confirmed & 0.11 \\
\hline & Will be informed & 0.01 \\
\hline & Disclaimed & 0.07 \\
\hline \multirow{10}{*}{$\begin{array}{l}\text { Contents of clear rumor } \\
\text { declaration }\end{array}$} & $\begin{array}{l}\text { Rising capital from renewal of } \\
\text { assessment of assets }\end{array}$ & 0.21 \\
\hline & $\begin{array}{l}\text { Increase in capital from the accumulated } \\
\text { profit }\end{array}$ & 0.02 \\
\hline & Increase in capital & 0.09 \\
\hline & Manufacturing of the new product & 0.03 \\
\hline & $\begin{array}{l}\text { Purchase and reconstruction of } \\
\text { equipment }\end{array}$ & 0.05 \\
\hline & Change of assets and liabilities & 0.02 \\
\hline & Publishing report & 0.02 \\
\hline & Export & 2 \\
\hline & Status of claims & 0.04 \\
\hline & Assignment of corporate stocks & 0.04 \\
\hline
\end{tabular}




\begin{tabular}{|l|l|c|}
\hline \multirow{4}{*}{} & Merger & 0.03 \\
\cline { 2 - 3 } (general) reappraisal & 0.02 \\
\cline { 2 - 3 } & Imposing sanction & 0.03 \\
\cline { 2 - 3 } & Food rate & 0.02 \\
\cline { 2 - 3 } & Ownership of property & 0.03 \\
\cline { 2 - 3 } & $\begin{array}{l}\text { Sale- change plan in sale rate and } \\
\text { quantity }\end{array}$ & 0.07 \\
\cline { 2 - 3 } & Tender- bid- contract and agreement & 0.09 \\
\cline { 2 - 3 } & Profit and its increase/ decrease & 0.03 \\
\cline { 2 - 3 } & Loss to enterprise & 0.02 \\
\cline { 2 - 3 } & Miscellaneous & 0.11 \\
\hline
\end{tabular}

\section{Dependent variable:}

To examine the impact of a clear rumor declaration, abnormal return is used as a criterion for the stock price in addition to stock return and it is computed and tested at two levels of abnormal return and cumulative abnormal return. The realized stock return $\left(\mathrm{R}_{\mathrm{i}, \mathrm{t}}\right)$ per day has been calculated as follows:

$$
\mathrm{Ri}_{\mathrm{t}}=\left(\mathrm{P}_{1}-\mathrm{P}_{0}\right) / \mathrm{P}_{0}
$$

$P_{1}$ : The final stock price at present-day

$P_{0}$ : Final stock price yesterday

Additional return per stock $\left(\mathrm{AR}_{\mathrm{i}, \mathrm{t}}\right)$ that is abnormal return includes difference among real and expected returns, which can be calculated as follows:

$$
A R_{i, t}=R_{i, t}-E\left(R_{i, t}\right)
$$

$E\left(R_{i, t}\right):$ Expected stock return

The modified market model has been utilized to compute (estimate) expected stock return. Therefore, by the implementation of the modified market model, the above-said equation will be expressed as follows:

$$
\begin{aligned}
& A R_{i, t}=R_{i, t}-R_{i, t-1} \\
& R_{m t}=\left(I_{m t}-I_{M 0}\right) / I_{M 0}
\end{aligned}
$$

Rmt: Market returns

Imt: Index in present day

Imo: Index yesterday 
Cumulative Abnormal Return (CAR), which is calculated to cover the full impact of an event on the stock price for the periods before and after the given event, includes the sum of each of abnormal returns during the period of tested items computed as follows (Asadi \& Kashani, 2018):

Cumulative Abnormal Return $(\mathrm{CAR})=\left(\mathrm{CAR}_{\mathrm{t}}\right)=\mid \sum_{i=1}^{n} A R$ it

Whereas stocks are subject to various types of data and some of this information may cause rising in their prices and some others can reduce the prices thus response to a certain event may be neutralized with reaction to other information. To solve this problem, the mean cumulative abnormal return for any newsgroup will be calculated for before and after news declaration (Dianati dalami \& Khodakarami, 2017):

$C A A R_{i, t}:$ Mean cumulative abnormal return

$$
\text { CAAR } i, t=\sum_{k=1}^{n} A A R \text { it }
$$

The rumors may affect only stock price in short term, but it does not impact on investors with long term objectives (Brown, 1980). The time cycle for even research includes estimation period and event period. The estimation period is longer than the event period and the valid event date is the same as the disclosure declaration date (Jun W. et al. 2016). Therefore, according to the study of Zhang et al. (2016) in this investigation, the expected return has been obtained during the estimated period including 242 days (e.g. one transactional year) before the event period (day of profit declaration within even period (-22$\mathrm{t}+10)$ ) and abnormal return behavior will be analyzed by separation of abnormal return from the expected return during the event period. The given event period has been considered because of conducting accurate and long term analysis on stock price behavior and also it should be noticed that assuming a longer period may increase the probability of impact of intervening variables while the shorter time period may also probably ignore the reaction of passive investors (Badri \& Asilzadeh, 2011).

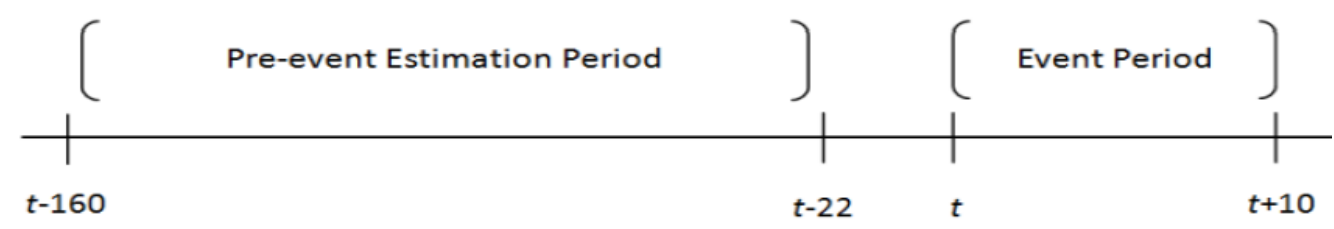

Figure 2. Time vector of event window (event period and estimation period) 


\section{Control variables}

The variables including the number of words and quantity of characters for the content of clear rumor declaration as well as the age of enterprise (e.g. in the study of Poorheidari et al. 2013) and change in management and type of ownership (e.g. in the survey of Arabi et al. 2017) will be employed as a control variable in order to control subsidiary factors over dependent variable (abnormal stock return) in this study. The age of the company denotes the number of years of corporate activity (Poornedari et al. 2013). Change of management is a virtual variable and it is rated by 1 for the enterprises in which managing directors have been changed since the last year and it is scored as 0 for other companies. Type of ownership is a virtual variable and it assumed as 1 for those companies in which at least $50 \%$ of their stocks belong to the government and its affiliated organizations (public companies) and it is assumed as zero for other enterprises (Arabi et al. 2017).

Table 3. Definition of the symbol used for regressive models

\begin{tabular}{|c|c|l|}
\hline $\begin{array}{c}\text { Type of } \\
\text { variable }\end{array}$ & Symbol & \multicolumn{1}{c|}{ Concept } \\
\hline \multirow{3}{*}{ Dependent } & Rit & Abnormal stock return at the day of clear rumor declaration \\
\cline { 2 - 3 } & Rit-22 & $\begin{array}{l}\text { Abnormal stock return 22 days before clear rumor } \\
\text { declaration }\end{array}$ \\
\cline { 2 - 3 } Independent & Rit+10 & Abnormal stock return 10 days after clear rumor declaration \\
\hline \multirow{4}{*}{ X1 } & $\begin{array}{l}\text { Independent variable at any hypothesis (the content of } \\
\text { rumors, confirmation of good and bad rumors, time of clear } \\
\text { rumor declaration) }\end{array}$ \\
\hline & $\mathrm{X} 2$ & Number of words in disclosure declaration \\
\cline { 2 - 3 } & DIR3 & Change of management (director) \\
\cline { 2 - 3 } & OWN4 & Type of ownership \\
\cline { 2 - 3 } & AGE5 & Age of company \\
\hline
\end{tabular}

\section{Event research}

Using event research methodology is one of the paramount and widest methodologies in financial markets to describe the behavior of the stock market. Event research is a type of study in which the researcher tends to analyze the behavior of stock price in enterprises that have experienced a common event. This type of research is deemed as a standard tool for measurement of one or more specific events on stock price in financial and accounting field where in most cases e.g. 
Application of event research technique is one of the foremost and most extensive methodologies to explain the behavior of stock returns in financial markets. The event research methodology is a study in which the researcher tries to review the behavior of stock price in enterprises where they have experienced a common event. This type of research is deemed as a standard tool for measurement of one or more specific events on stock price in financial and accounting field where in most cases e.g. impacts of declaration of accounting reports and stock price or analysis may be applicable (Ghaemi, 2009). Event research is an empirical methodology for analyzing the performance of enterprises after the occurrence of an event. There are 3 key factors in event research including event, abnormal return during the event period and statistical significance of abnormal return. The literature of event research is addressed in two general classes: event time approach and calendar time approach. To analyze short term and long term performance of enterprises, the event-time approach (based on event time) is often taken in event research studies. In this technique, a certain event is considered for all enterprises and the event date is determined for typical enterprises. If event date varies for all enterprises, but it is assumed as starting time or zero time $(\mathrm{t}=0)$, this means although the points of their starting are different, a common point is considered for them (Rahimpoor \& Ghaemi, 2019).

\section{Research findings}

\section{Testing of findings}

\section{First major hypothesis}

it is visible that the variable of good and bad rumors is significant at both levels $(\mathrm{P}>0.05)$. Therefore, it does not affect the significantly abnormal return and it can be implied that the content of rumors does not impact abnormal stock return. The modified determination coefficient (AVE) is 0.05 that shows that the existing independent and control variables in the model could explain 5 percent of the variance in the dependent variable. Fisher's F-statistic is significant at less than 0.05 . Thus, it can be mentioned that the fitting model is adequately valid. Likewise, the Durbin-Watson statistic is 2.314 and it is placed among 1.5 and 2.5 and indicates a lack of first-order autocorrelation problem in this model. 


\section{8}

Iranian Journal of Finance, 2021, Vol. 5, No. 3 (Hatam, J.)

Table 5: Final estimation of the regressive model in the first major hypothesis (Good and bad rumors with abnormal return)

\begin{tabular}{|c|c|c|c|c|c|c|c|}
\hline \multirow[b]{2}{*}{ Variables } & \multicolumn{3}{|c|}{ Good rumors } & & \multicolumn{3}{|c|}{ Bad rumors } \\
\hline & $\begin{array}{c}\text { Coeffici } \\
\text { ent }\end{array}$ & $\begin{array}{l}\text { Significa } \\
\text { nce level }\end{array}$ & $\begin{array}{c}\text { Collinea } \\
\text { rity }\end{array}$ & & $\begin{array}{c}\text { Coeffici } \\
\text { ent }\end{array}$ & $\begin{array}{l}\text { Significa } \\
\text { nce level }\end{array}$ & $\begin{array}{l}\text { Collinea } \\
\text { rity }\end{array}$ \\
\hline $\begin{array}{l}\text { Good } \\
\text { rumor }\end{array}$ & 0.012 & 0.277 & 1.034 & Bad rumor & -0.014 & 0.231 & 1.031 \\
\hline $\begin{array}{l}\text { Number of } \\
\text { words in } \\
\text { disclosure } \\
\text { declaration }\end{array}$ & 0.011 & 0.285 & 1.027 & $\begin{array}{c}\text { Number of } \\
\text { words in } \\
\text { disclosure } \\
\text { declaration }\end{array}$ & 0.011 & 0.280 & 1.025 \\
\hline $\begin{array}{c}\text { Change of } \\
\text { director }\end{array}$ & -0.021 & 0.027 & 1.051 & $\begin{array}{c}\text { Change of } \\
\text { director }\end{array}$ & -0.021 & 0.027 & 1.051 \\
\hline $\begin{array}{c}\text { Public } \\
\text { ownership }\end{array}$ & -0.007 & 0.426 & 1.003 & $\begin{array}{c}\text { Public } \\
\text { ownership }\end{array}$ & -0.007 & 0.440 & 1.004 \\
\hline $\begin{array}{c}\text { Age of } \\
\text { company }\end{array}$ & 0.022 & 0.004 & 1.055 & $\begin{array}{l}\text { Age of } \\
\text { company }\end{array}$ & 0.022 & 0.004 & 1.053 \\
\hline Intercept & -0.114 & 0.043 & & Intercept & -0.101 & 0.063 & \\
\hline $\begin{array}{c}\text { Variance } \\
\text { inequality } \\
\text { test }\end{array}$ & \multicolumn{3}{|c|}{$0.646(0.664)$} & $\begin{array}{c}\text { Variance } \\
\text { inequality } \\
\text { test }\end{array}$ & \multicolumn{3}{|c|}{$0.642(0.667)$} \\
\hline $\begin{array}{c}\text { Serial } \\
\text { autocorrela } \\
\text { tion test }\end{array}$ & \multicolumn{3}{|c|}{$1.502(0.225)$} & $\begin{array}{c}\text { Serial } \\
\text { autocorrela } \\
\text { tion test }\end{array}$ & \multicolumn{3}{|c|}{$1.866(0.158)$} \\
\hline AVE & \multicolumn{3}{|c|}{0.079} & AVE & \multicolumn{3}{|c|}{0.081} \\
\hline $\begin{array}{c}\text { Modified } \\
\text { AVE }\end{array}$ & \multicolumn{3}{|c|}{0.051} & $\begin{array}{c}\text { Modified } \\
\text { AVE }\end{array}$ & \multicolumn{3}{|c|}{0.053} \\
\hline $\begin{array}{l}\text { Fisher's } \\
\text { statistic }\end{array}$ & \multicolumn{3}{|c|}{2.834} & $\begin{array}{l}\text { Fisher's } \\
\text { statistic }\end{array}$ & \multicolumn{3}{|c|}{2.889} \\
\hline $\begin{array}{c}\text { Fisher's } \\
\text { significanc } \\
\text { e level }\end{array}$ & \multicolumn{3}{|c|}{0.017} & $\begin{array}{c}\text { Fisher's } \\
\text { significanc } \\
\text { e level }\end{array}$ & \multicolumn{3}{|c|}{0.015} \\
\hline $\begin{array}{l}\text { Durbin- } \\
\text { Watson }\end{array}$ & \multicolumn{3}{|c|}{2.113} & $\begin{array}{l}\text { Durbin- } \\
\text { Watson }\end{array}$ & \multicolumn{3}{|c|}{2.121} \\
\hline
\end{tabular}

Table 6: Final estimation of the regressive model in the first major hypothesis (Good and bad rumors with abnormal return after 10 days)

\begin{tabular}{|c|c|c|c|c|c|c|c|}
\hline \multirow{2}{*}{ Variables } & \multicolumn{3}{|c|}{ Good rumors } & & \multicolumn{3}{c|}{ Bad rumors } \\
\cline { 2 - 4 } \cline { 5 - 7 } & $\begin{array}{c}\text { Coeffici } \\
\text { ent }\end{array}$ & $\begin{array}{c}\text { Significa } \\
\text { nce level }\end{array}$ & $\begin{array}{c}\text { Collinea } \\
\text { rity }\end{array}$ & & $\begin{array}{c}\text { Coeffici } \\
\text { ent }\end{array}$ & $\begin{array}{c}\text { Significa } \\
\text { nce level }\end{array}$ & $\begin{array}{c}\text { Collinea } \\
\text { rity }\end{array}$ \\
\hline $\begin{array}{c}\text { Good } \\
\text { rumor }\end{array}$ & 0.210 & 0.000 & 1.034 & Bad rumor & -0.165 & 0.000 & 1.031 \\
\hline $\begin{array}{c}\text { Number of } \\
\text { words in } \\
\text { disclosure }\end{array}$ & 0.007 & 0.560 & 1.027 & $\begin{array}{c}\text { Number of } \\
\text { words in } \\
\text { disclosure }\end{array}$ & 0.007 & 0.597 & 1.025 \\
\hline
\end{tabular}


The Event Research in the Effect of Clear Rumor Declarations ...

\begin{tabular}{|c|c|c|c|c|c|c|c|}
\hline declaration & & & & declaration & & & \\
\hline $\begin{array}{c}\text { Change of } \\
\text { director }\end{array}$ & 0.008 & 0.485 & 1.051 & $\begin{array}{c}\text { Change of } \\
\text { director }\end{array}$ & 0.008 & 0.487 & 1.051 \\
\hline $\begin{array}{c}\text { Public } \\
\text { ownership }\end{array}$ & -0.009 & 0.454 & 1.003 & $\begin{array}{c}\text { Public } \\
\text { ownership }\end{array}$ & -0.009 & 0.440 & 1.004 \\
\hline $\begin{array}{c}\text { Age of } \\
\text { company }\end{array}$ & -0.005 & 0.571 & 1.055 & $\begin{array}{l}\text { Age of } \\
\text { company }\end{array}$ & -0.005 & 0.593 & 1.053 \\
\hline Intercept & -0.007 & 0.919 & & Intercept & -0.011 & 0.868 & \\
\hline $\begin{array}{c}\text { Variance } \\
\text { inequality } \\
\text { test }\end{array}$ & \multicolumn{3}{|c|}{$0.680(0.639)$} & $\begin{array}{c}\text { Variance } \\
\text { inequality } \\
\text { test }\end{array}$ & \multicolumn{3}{|c|}{$0.682(0.637)$} \\
\hline $\begin{array}{c}\text { Serial } \\
\text { autocorrela } \\
\text { tion test }\end{array}$ & \multicolumn{3}{|c|}{$0.107(0.898)$} & $\begin{array}{c}\text { Serial } \\
\text { autocorrela } \\
\text { tion test }\end{array}$ & \multicolumn{3}{|c|}{$0.107(0.897)$} \\
\hline AVE & \multicolumn{3}{|c|}{0.125} & AVE & \multicolumn{3}{|c|}{0.132} \\
\hline $\begin{array}{c}\text { Modified } \\
\text { AVE }\end{array}$ & \multicolumn{3}{|c|}{0.102} & $\begin{array}{l}\text { Modified } \\
\text { AVE }\end{array}$ & \multicolumn{3}{|c|}{0.112} \\
\hline $\begin{array}{l}\text { Fisher's } \\
\text { statistic }\end{array}$ & \multicolumn{3}{|c|}{9.203} & $\begin{array}{l}\text { Fisher's } \\
\text { statistic }\end{array}$ & \multicolumn{3}{|c|}{14.203} \\
\hline $\begin{array}{c}\text { Fisher's } \\
\text { significanc } \\
\text { e level }\end{array}$ & \multicolumn{3}{|c|}{0.000} & $\begin{array}{c}\text { Fisher's } \\
\text { significanc } \\
\text { e level }\end{array}$ & \multicolumn{3}{|c|}{0.000} \\
\hline $\begin{array}{l}\text { Durbin- } \\
\text { Watson }\end{array}$ & \multicolumn{3}{|c|}{2.059} & $\begin{array}{l}\text { Durbin- } \\
\text { Watson }\end{array}$ & \multicolumn{3}{|c|}{2.065} \\
\hline
\end{tabular}

It is seen that the variable of good rumors has a positive coefficient with a significance level smaller than 0.05 . Thus, it can be mentioned that the variable of good rumors will increase abnormal return after 10 days. Similarly, the variable of bad rumors has a negative coefficient with a significance level of less than 5 percent. It can be implied that the variable of bad rumors will decrease abnormal return after 10 days.

Table 7. Final estimation of the regressive model in the first major hypothesis (Good and bad rumors with abnormal return within 22 days ago)

\begin{tabular}{|c|c|c|c|c|c|c|c|}
\hline \multirow{2}{*}{ Variables } & \multicolumn{3}{|c|}{ Good rumors } & \multicolumn{3}{c|}{ Bad rumors } \\
\cline { 2 - 4 } \cline { 5 - 7 } & $\begin{array}{c}\text { Coeffici } \\
\text { ent }\end{array}$ & $\begin{array}{c}\text { Significa } \\
\text { nce level }\end{array}$ & $\begin{array}{c}\text { Collinea } \\
\text { rity }\end{array}$ & & $\begin{array}{c}\text { Coeffici } \\
\text { ent }\end{array}$ & $\begin{array}{c}\text { Significa } \\
\text { nce level }\end{array}$ & $\begin{array}{c}\text { Collinea } \\
\text { rity }\end{array}$ \\
\hline $\begin{array}{c}\text { Good } \\
\text { rumor }\end{array}$ & 0.149 & 0.442 & 1.034 & Bad rumor & -0.147 & 0.468 & 1.031 \\
\hline $\begin{array}{c}\text { Number of } \\
\text { words in } \\
\text { disclosure } \\
\text { declaration }\end{array}$ & -0.016 & 0.922 & 1.027 & $\begin{array}{c}\text { Number of } \\
\text { words in } \\
\text { disclosure } \\
\text { declaration }\end{array}$ & -0.018 & 0.912 & 1.025 \\
\hline
\end{tabular}


Iranian Journal of Finance, 2021, Vol. 5, No. 3 (Hatam, J.)

\begin{tabular}{|c|c|c|c|c|c|c|c|}
\hline $\begin{array}{c}\text { Change of } \\
\text { director }\end{array}$ & 0.014 & 0.000 & 1.051 & $\begin{array}{c}\text { Change of } \\
\text { director }\end{array}$ & 0.014 & 0.000 & 1.051 \\
\hline $\begin{array}{c}\text { Public } \\
\text { ownership }\end{array}$ & 0.068 & 0.668 & 1.003 & $\begin{array}{c}\text { Public } \\
\text { ownership }\end{array}$ & 0.070 & 0.659 & 1.004 \\
\hline $\begin{array}{l}\text { Age of } \\
\text { company }\end{array}$ & -0.128 & 0.328 & 1.055 & $\begin{array}{l}\text { Age of } \\
\text { company }\end{array}$ & -0.126 & 0.334 & 1.053 \\
\hline Intercept & 0.465 & 0.614 & & Intercept & 0.614 & 0.492 & \\
\hline $\begin{array}{c}\text { Variance } \\
\text { inequality } \\
\text { test }\end{array}$ & \multicolumn{3}{|c|}{$0.375(0.865)$} & $\begin{array}{c}\text { Variance } \\
\text { inequality } \\
\text { test }\end{array}$ & \multicolumn{3}{|c|}{$0.357(0.877)$} \\
\hline $\begin{array}{c}\text { Serial } \\
\text { autocorrela } \\
\text { tion test }\end{array}$ & \multicolumn{3}{|c|}{$0.271(0.762)$} & $\begin{array}{c}\text { Serial } \\
\text { autocorrela } \\
\text { tion test }\end{array}$ & \multicolumn{3}{|c|}{$0.265(0.767)$} \\
\hline AVE & \multicolumn{3}{|c|}{0.098} & AVE & \multicolumn{3}{|c|}{0.102} \\
\hline $\begin{array}{c}\text { Modified } \\
\text { AVE }\end{array}$ & \multicolumn{3}{|c|}{0.085} & $\begin{array}{l}\text { Modified } \\
\text { AVE }\end{array}$ & \multicolumn{3}{|c|}{0.095} \\
\hline $\begin{array}{l}\text { Fisher's } \\
\text { statistic }\end{array}$ & \multicolumn{3}{|c|}{27.203} & $\begin{array}{l}\text { Fisher's } \\
\text { statistic }\end{array}$ & \multicolumn{3}{|c|}{28.203} \\
\hline $\begin{array}{l}\text { Fisher's } \\
\text { significanc } \\
\text { e level } \\
\end{array}$ & \multicolumn{3}{|c|}{0.000} & $\begin{array}{c}\text { Fisher's } \\
\text { significanc } \\
\text { e level }\end{array}$ & \multicolumn{3}{|c|}{0.000} \\
\hline $\begin{array}{l}\text { Durbin- } \\
\text { Watson }\end{array}$ & \multicolumn{3}{|c|}{2.029} & $\begin{array}{l}\text { Durbin- } \\
\text { Watson }\end{array}$ & \multicolumn{3}{|c|}{2.028} \\
\hline
\end{tabular}

According to the results in Table 4, it is visible that the variable of good and bad rumors is significant at two levels greater than 5\%. Therefore, it does not affect significantly abnormal return within 22 days ago and it can be said the variable of the content of rumors does not affect the abnormal stock return.

\section{Second major hypothesis}

Table 8. Final estimation of the regressive model in second major hypothesis

(Confirmation of good rumors and abnormal return, abnormal return at 10 subsequent days, abnormal return within 22 days ago)

\begin{tabular}{|c|c|c|c|c|c|c|c|c|c|}
\hline \multirow{2}{*}{$\begin{array}{c}\text { Variable } \\
\text { s }\end{array}$} & \multicolumn{9}{c|}{ Confirmation of good rumors } \\
\cline { 2 - 9 } & \multicolumn{2}{|c|}{ Abnormal return } & \multicolumn{2}{c|}{$\begin{array}{c}\text { Abnormal return after 10 } \\
\text { days }\end{array}$} & \multicolumn{2}{c|}{$\begin{array}{c}\text { Abnormal return in } 22 \\
\text { days ago }\end{array}$} \\
\hline Coeffi & $\begin{array}{c}\text { Signifi } \\
\text { cance } \\
\text { cient }\end{array}$ & $\begin{array}{c}\text { Collin } \\
\text { earity }\end{array}$ & $\begin{array}{c}\text { Coeffi } \\
\text { cient }\end{array}$ & $\begin{array}{c}\text { Signifi } \\
\text { cance } \\
\text { level }\end{array}$ & $\begin{array}{c}\text { Collin } \\
\text { earity }\end{array}$ & $\begin{array}{c}\text { Coeffi } \\
\text { cient }\end{array}$ & $\begin{array}{c}\text { Signifi } \\
\text { cance } \\
\text { level }\end{array}$ & $\begin{array}{c}\text { Collin } \\
\text { earity }\end{array}$ \\
\hline
\end{tabular}


The Event Research in the Effect of Clear Rumor Declarations ...

\begin{tabular}{|c|c|c|c|c|c|c|c|c|c|}
\hline rumor & & & & & & & & & \\
\hline $\begin{array}{l}\text { Number } \\
\text { of words } \\
\text { in } \\
\text { disclosu } \\
\text { re } \\
\text { declarati } \\
\text { on } \\
\end{array}$ & 0.009 & 0.365 & 1.004 & 0.009 & 0.489 & 1.004 & -0.033 & 0.841 & 1.004 \\
\hline $\begin{array}{l}\text { Change } \\
\text { of } \\
\text { director }\end{array}$ & -0.021 & 0.026 & 1.052 & 0.009 & 0.447 & 1.052 & 0.016 & 0.000 & 1.052 \\
\hline $\begin{array}{c}\text { Public } \\
\text { ownersh } \\
\text { ip }\end{array}$ & -0.008 & 0.387 & 1.054 & -0.004 & 0.729 & 1.054 & 0.091 & 0.577 & 1.54 \\
\hline $\begin{array}{c}\text { Age of } \\
\text { compan } \\
y\end{array}$ & 0.023 & 0.004 & 1.062 & -0.004 & 0.699 & 1.062 & -0.106 & 0.418 & 1.062 \\
\hline $\begin{array}{c}\text { Intercep } \\
\mathrm{t}\end{array}$ & -0.098 & 0.075 & & -0.020 & 0.769 & & 0.607 & 0.497 & \\
\hline $\begin{array}{c}\text { Varianc } \\
\mathrm{e} \\
\text { inequalit } \\
\mathrm{y} \text { test }\end{array}$ & \multicolumn{3}{|c|}{$1.256(0.285)$} & \multicolumn{3}{|c|}{$1.196(0.313)$} & \multicolumn{3}{|c|}{$0.358(0.876)$} \\
\hline $\begin{array}{c}\text { Serial } \\
\text { autocorr } \\
\text { elation } \\
\text { test }\end{array}$ & \multicolumn{3}{|c|}{$1.410(0.247)$} & \multicolumn{3}{|c|}{$0.229(0.795)$} & \multicolumn{3}{|c|}{$0.275(0.759)$} \\
\hline AVE & \multicolumn{3}{|c|}{0.073} & \multicolumn{3}{|c|}{0.089} & \multicolumn{3}{|c|}{0.095} \\
\hline $\begin{array}{l}\text { Modifie } \\
\text { d AVE }\end{array}$ & \multicolumn{3}{|c|}{0.045} & \multicolumn{3}{|c|}{0.074} & \multicolumn{3}{|c|}{0.085} \\
\hline $\begin{array}{l}\text { Fisher's } \\
\text { statistic }\end{array}$ & \multicolumn{3}{|c|}{2.601} & \multicolumn{3}{|c|}{21.203} & \multicolumn{3}{|c|}{22.365} \\
\hline $\begin{array}{c}\text { Fisher's } \\
\text { significa } \\
\text { nce } \\
\text { level }\end{array}$ & \multicolumn{3}{|c|}{0.027} & \multicolumn{3}{|c|}{0.000} & \multicolumn{3}{|c|}{0.000} \\
\hline $\begin{array}{l}\text { Durbin- } \\
\text { Watson }\end{array}$ & \multicolumn{3}{|c|}{2.102} & \multicolumn{3}{|c|}{2.101} & \multicolumn{3}{|c|}{ 2. 019} \\
\hline
\end{tabular}

It is observed that confirmation of good rumor has a direct and significant impact on abnormal return only after 10 days while it does not affect abnormal return at the day of disclosure declaration and abnormal return within 22 days ago. 


\section{Third major hypothesis}

Table 9. Final estimation of the regressive model in third major hypothesis

(Confirmation of bad rumors and abnormal return, abnormal return at 10 subsequent days, abnormal return within 22 days ago)

\begin{tabular}{|c|c|c|c|c|c|c|c|c|c|}
\hline \multirow[b]{3}{*}{ Variables } & \multicolumn{9}{|c|}{ Confirmation of bad rumors } \\
\hline & \multicolumn{3}{|c|}{ Abnormal return } & \multicolumn{3}{|c|}{$\begin{array}{c}\text { Abnormal return after } 10 \\
\text { days }\end{array}$} & \multicolumn{3}{|c|}{$\begin{array}{c}\text { Abnormal return in } 22 \\
\text { days ago }\end{array}$} \\
\hline & $\begin{array}{l}\text { Coe } \\
\text { ffici } \\
\text { ent }\end{array}$ & $\begin{array}{l}\text { Signif } \\
\text { icanc } \\
\mathrm{e} \\
\text { level }\end{array}$ & $\begin{array}{l}\text { Colline } \\
\text { arity }\end{array}$ & $\begin{array}{l}\text { Coef } \\
\text { ficie } \\
\text { nt }\end{array}$ & $\begin{array}{l}\text { Signifi } \\
\text { cance } \\
\text { level }\end{array}$ & $\begin{array}{l}\text { Collin } \\
\text { earity }\end{array}$ & $\begin{array}{l}\text { Coeffi } \\
\text { cient }\end{array}$ & $\begin{array}{l}\text { Signifi } \\
\text { cance } \\
\text { level }\end{array}$ & $\begin{array}{l}\text { Collin } \\
\text { earity }\end{array}$ \\
\hline Bad rumor & $\begin{array}{c}- \\
0.03 \\
1\end{array}$ & 0.063 & 1.029 & $\stackrel{-}{0.001}$ & 0.961 & 1.029 & -0.135 & 0.623 & 1.029 \\
\hline $\begin{array}{l}\text { Number of } \\
\text { words in } \\
\text { disclosure } \\
\text { declaration } \\
\end{array}$ & $\begin{array}{c}0.01 \\
2\end{array}$ & 0.229 & 1.028 & 0.008 & 0.519 & 1.028 & -0.023 & 0.890 & 1.028 \\
\hline $\begin{array}{l}\text { Change of } \\
\text { director }\end{array}$ & $\begin{array}{c}- \\
0.02 \\
1 \\
\end{array}$ & 0.027 & 1.051 & 0.008 & 0.000 & 1.051 & 0.014 & 0.000 & 1.051 \\
\hline $\begin{array}{c}\text { Public } \\
\text { ownership }\end{array}$ & $\begin{array}{c}- \\
0.00 \\
7\end{array}$ & 0.421 & 1.003 & $\begin{array}{c}- \\
0.009\end{array}$ & 0.458 & 1.003 & 0.067 & 0.675 & 1.003 \\
\hline $\begin{array}{l}\text { Age of } \\
\text { company }\end{array}$ & $\begin{array}{c}0.02 \\
2\end{array}$ & 0.004 & 1.049 & $\begin{array}{c}- \\
0.006 \\
\end{array}$ & 0.544 & 1.049 & -0.122 & 0.351 & 1.049 \\
\hline Intercept & $\begin{array}{c}- \\
0.10 \\
7\end{array}$ & 0.050 & & $\stackrel{-}{0.014}$ & 0.840 & & 0.606 & 0.499 & \\
\hline $\begin{array}{c}\text { Variance } \\
\text { inequality } \\
\text { test } \\
\end{array}$ & \multicolumn{3}{|c|}{$0.669(0.647)$} & \multicolumn{3}{|c|}{$0.657(0.656)$} & \multicolumn{3}{|c|}{$0.290(0.917)$} \\
\hline $\begin{array}{c}\text { Serial } \\
\text { autocorrelat } \\
\text { ion test }\end{array}$ & \multicolumn{3}{|c|}{$1.890(0.154)$} & \multicolumn{3}{|c|}{$0.086(0.908)$} & \multicolumn{3}{|c|}{$0.235(0.790)$} \\
\hline $\mathrm{AVE}$ & \multicolumn{3}{|c|}{0.092} & \multicolumn{3}{|c|}{0.096} & \multicolumn{3}{|c|}{0.102} \\
\hline $\begin{array}{l}\text { Modified } \\
\text { AVE }\end{array}$ & \multicolumn{3}{|c|}{0.064} & \multicolumn{3}{|c|}{0.085} & \multicolumn{3}{|c|}{0.095} \\
\hline $\begin{array}{l}\text { Fisher's } \\
\text { statistic }\end{array}$ & \multicolumn{3}{|c|}{3.332} & \multicolumn{3}{|c|}{23.256} & \multicolumn{3}{|c|}{25.265} \\
\hline $\begin{array}{c}\text { Fisher's } \\
\text { significance } \\
\text { level }\end{array}$ & \multicolumn{3}{|c|}{0.006} & \multicolumn{3}{|c|}{0.000} & \multicolumn{3}{|c|}{0.000} \\
\hline $\begin{array}{l}\text { Durbin- } \\
\text { Watson }\end{array}$ & \multicolumn{3}{|c|}{2.131} & \multicolumn{3}{|c|}{2.059} & \multicolumn{3}{|c|}{2.023} \\
\hline
\end{tabular}


It is seen that confirmation of bad rumors has reduced abnormal return at $10 \%$ of error level at declaration day and it has no impact on abnormal return within 22 days ago and after 10 days.

\section{Fourth major hypothesis}

Table 10. Final estimation of the regressive model in fourth major hypothesis

(Time of issuing disclosure declaration and abnormal return, abnormal return at 10 subsequent days, abnormal return within 22 days ago)

\begin{tabular}{|c|c|c|c|c|c|c|c|c|c|}
\hline \multirow[b]{3}{*}{ Variables } & \multicolumn{9}{|c|}{ Time of issuing disclosure declaration } \\
\hline & \multicolumn{3}{|c|}{ Abnormal return } & \multicolumn{3}{|c|}{$\begin{array}{l}\text { Abnormal return after } 10 \\
\text { days }\end{array}$} & \multicolumn{3}{|c|}{$\begin{array}{l}\text { Abnormal return in } 22 \\
\text { days ago }\end{array}$} \\
\hline & $\begin{array}{l}\text { Coeff } \\
\text { icient }\end{array}$ & $\begin{array}{l}\text { Signif } \\
\text { icanc } \\
\text { e } \\
\text { level }\end{array}$ & $\begin{array}{l}\text { Colli } \\
\text { nearit } \\
\mathrm{y}\end{array}$ & $\begin{array}{l}\text { Coeff } \\
\text { icient }\end{array}$ & $\begin{array}{l}\text { Signific } \\
\text { ance } \\
\text { level }\end{array}$ & $\begin{array}{l}\text { Colli } \\
\text { nearit } \\
\text { y }\end{array}$ & $\begin{array}{l}\text { Coeff } \\
\text { icient }\end{array}$ & $\begin{array}{l}\text { Signif } \\
\text { icanc } \\
\text { e } \\
\text { level }\end{array}$ & $\begin{array}{l}\text { Colli } \\
\text { nearit } \\
\mathrm{y}\end{array}$ \\
\hline $\begin{array}{l}\text { Time of } \\
\text { issuing } \\
\text { disclosure } \\
\text { declaration }\end{array}$ & $-\overline{0}-$ & 0.042 & 1.016 & 0.015 & 0.276 & $1 / 016$ & 0.173 & 0.339 & 1.016 \\
\hline $\begin{array}{ll}\text { Number } & \text { of } \\
\text { words } & \text { in } \\
\text { disclosure } & \\
\text { declaration } & \end{array}$ & 0.008 & 0.395 & 1.005 & 0.009 & 0.492 & 1.005 & $\overline{0} .030$ & 0.855 & 1.005 \\
\hline $\begin{array}{l}\text { Change of } \\
\text { director }\end{array}$ & $-\overline{0}$ & 0.026 & 1.051 & 0.008 & 0.000 & 1.051 & 0.011 & 0.000 & 1.051 \\
\hline $\begin{array}{l}\text { Public } \\
\text { ownership }\end{array}$ & $\begin{array}{l}- \\
0.010\end{array}$ & 0.297 & 1.015 & $-\overline{0} 007$ & 0.535 & 1.015 & 0.083 & 0.604 & 1.015 \\
\hline $\begin{array}{ll}\begin{array}{l}\text { Age } \\
\text { company }\end{array} & \text { of } \\
\end{array}$ & 0.024 & 0.002 & 1.047 & $\begin{array}{l}- \\
-006\end{array}$ & 0.511 & 1.047 & $-\overline{0}$ & 0.342 & 1.047 \\
\hline Intercept & $\overline{0} 0.092$ & 0.092 & & $\overline{0}-018$ & -0.789 & & 0.586 & 0.512 & \\
\hline $\begin{array}{l}\text { Variance } \\
\text { inequality test }\end{array}$ & \multicolumn{3}{|c|}{$0.607(0.694)$} & \multicolumn{3}{|c|}{$0.704(0.620)$} & \multicolumn{3}{|c|}{$0.409(0.841)$} \\
\hline $\begin{array}{l}\text { Serial } \\
\text { autocorrelatio } \\
\mathrm{n} \text { test }\end{array}$ & \multicolumn{3}{|c|}{$1.773(0.173)$} & \multicolumn{3}{|c|}{$0.040(0.960)$} & \multicolumn{3}{|c|}{$0.214(0.807)$} \\
\hline AVE & \multicolumn{3}{|l|}{0.096} & \multicolumn{3}{|l|}{0.095} & \multicolumn{3}{|l|}{0.085} \\
\hline $\begin{array}{l}\text { Modified } \\
\text { AVE }\end{array}$ & \multicolumn{3}{|l|}{0.068} & \multicolumn{3}{|l|}{0.085} & \multicolumn{3}{|l|}{0.074} \\
\hline $\begin{array}{l}\text { Fisher's } \\
\text { statistic }\end{array}$ & \multicolumn{3}{|l|}{3.476} & \multicolumn{3}{|c|}{25.202} & \multicolumn{3}{|c|}{29.205} \\
\hline $\begin{array}{l}\text { Fisher's } \\
\text { significance } \\
\text { level }\end{array}$ & \multicolumn{3}{|l|}{0.005} & \multicolumn{3}{|l|}{0.000} & \multicolumn{3}{|l|}{0.000} \\
\hline $\begin{array}{l}\text { Durbin- } \\
\text { Watson }\end{array}$ & \multicolumn{3}{|l|}{2.110} & \multicolumn{3}{|l|}{2.040} & \multicolumn{3}{|l|}{2.036} \\
\hline
\end{tabular}


It is also seen if a clear rumor declaration is issued within working hours of the exchange market it reduces the abnormal return on the same day but it does not affect abnormal return within 22 days ago and after 10 days.

\section{Conclusion and Suggestions}

It has been dealt with event research based on clear rumor declarations in this study using regression analysis and correlation tests to measure the abnormal stock return. One can reveal the impact of an event on financial variables only through event research. Similarly, the regressive relationship was established among the return and clear rumor declaration in the presence of control variables for more sensitivity analysis. Given theoretical bases and benefitting from the conducted studies by domestic and foreign researchers and Using Spss statistical software version 26 and Eviews version 12, testing of hypothesis shows in this study that content or rumors will not affect the abnormal stock return. Namely, trust in the content of disclosure declarations by shareholders will be reduced under declaration condition and this factor gradually leads to reduced trust in reports of the TEDAN system and CODAL website. The results do not interpret the preference of informative content in disclosure declarations for the explanation of abnormal return and market actors could not acquire an abnormal return. Likewise, the findings of this study show that confirmation of good rumors has a direct and significant impact on abnormal return after 10 days, but it has no effect on abnormal return on the day of declaration and 22 days before the date of disclosure declaration. In other words, shareholders positively react to confirmation of good rumors until 10 days after the date of declaration and this leads to rising stock price. In addition, this study revealed that confirmation of bad rumors has reduced return on the day of declaration while it has no impact on abnormal return 22 days before declaration date and after 10 days. Namely, the market will fine all enterprises that have confirmed bad rumors at declaration day and reduced the return at declaration day and it may affect stock price in these companies at a lower intensity. As a result, if information disclosure declarations are issued during working hours of the market they will reduce the stock return on the same day. In other words, shareholders are sensitive at the time of disclosure declaration and they do not assume disclosure declaration as signs of return during working hours so this subject will inversely affect stock return for these enterprises. No certain study has been already carried out on the effect of clear rumor declarations. Thus, the results of this study are not directly comparable with findings of other investigations, but they are indirectly related to other several investigations for example (Peinan J. et al. 
2020; Qianwei Y. et al 2019; Wang, Jun et al. 2017; Xiaolan Y. Jianfang Z. 2016; Zhang N. and Liu C.L., 2012). In their surveys, they indicated that the variables of confirmation of rumors, disclosure declaration time and content of rumors might affect the abnormal stock return.

This study was followed with several limitations. Due to lack of timely presentation of information, some enterprises will have long delays and signs were mainly closed for several days and then opened. In addition to the aforesaid cases in this study, other factors can also affect the stock return. Therefore, lack of control over other effective variables of stock return was one of the limitations of this study. These findings provide a valuable reference for listed firms, Securities Regulatory Commission, and investors. In particular, listed firms should take a timely and proper response to clarify rumors since rumor clarification can further affect stock prices. It is also of great necessity for the securities Regulatory Commission to set rules for rumor clarification to prevent rumor speculators utilize rumor clarification as a second chance to spread rumors. In this study, we argue that the information bias of irrational investors may block valuable information which results in further market fluctuations if the market lacks sufficient credits. Information and credibility enhance information transparency interactively.

Funding: This research received no external funding.

\section{References}

Arabi, M., Taghavi, M., Royayee, R., Banimahd, B. (2017). The Financial Consequences of Increased Economic Sanctions. Journal of Financial Accounting Knowledge, 4(2), 27-52.

Asadi, Gh H. Ashlani, Behrouz, (2017). Analysis of the effect of changing auditor on the stock price. Journal of Quarterly of Auditing Science,17(66), 41-60.

Badri, A., Asilzadeh, M. (2011). Frequency and amplitude of price fluctuations: Evidence from Tehran Stock Exchange. Accounting and Auditing Research, 3(9), 5673. doi: 10.22034/iaar.2011.104765.

Bommel, J.V. 2003. "Rumors.” Journal of Finance 58, no. 4: 1499-1520.

Dewa,G,W, I Gusti, B,W,Zuraidah,M,A,Soheil k,.(2017). Price Manipulation by Dissemination of Rumors: Evidence from the Indonesian Stock Market. International Journal of Economics and Financial Issues, 7(1), 429-434. 
Dianati dalami, Z., Khodakarami, E. (2017). The impact of environmental news on stock prices of companies listed in Tehran Stock Exchange. Journal of Investment Knowledge, 6(23), 189-212.

Ghaemi, M H,. (2009). A review on the methodology of event researches. Journal of accounting knowledge and study, 5(17), 1-6.

Ghaemi, M H. Asgarzadeh, Gh. Masoumi, J,. (2012). Evaluation of the efficiency of accounting variables in the measurement of abnormal return in event research. Journal of Quarterly of accounting and auditing studies, 19(4), 79-100.

Ghaemi, M H. Masoumi, J,. (2011). To specify period of event time range for event researches in Tehran Stock Exchange, Journal of Accounting Knowledge Quarterly, 2(6), 7-25.

Junwang, Zh x. Qingli, J. Rong X. Yuanzhu ch. Fengyn w,.(2019) Effect of digitalized rumor clarification on stock markets. Journal of Emerging markets finance and trade,55(2).

Kiymaz, A,. (2001). The Effects Of Stock Market Rumors On Stock Prices: Evidence From an Emerging Market", Journal of Multinational Financial Management, 11(1), 105- 115.

Movafaghi, M.Tehrani, R. Baharvand, S,. (2011). The Effects of Rumors on Under-standing and Behavior of Investors in Tehran Stock Market. Two volumes of Daneshvar Quarterly, Progress and management,9(47),359-370.

Peinan, J. Xiangbin, Y.Guang, Y.(2020). Can Rumor Clarification Eliminate the Effects of Rumors? Evidence From China. International Journal of Asian Business and Information Management,11(1).

Pourheidari, O., Badri Khireh Masjedi, A. (2014). Studying the Effects of Rotation of Audit Firms and Audit Partner on Annual Adjustments and Audit Quality. Journal of Accounting Advances, 5(2), 1-24.

Ghaemi, M., Rahimpour, M. (2019). Evaluation of The Pricing Model and Calendar-Time Portfolio Approach in Long-Term Event Study. Empirical Studies in Financial Accounting, 15(61), 101-130. doi: 10.22054/qjma.2019.41172.1991

Rose, A.M. (1951). Rumor in The Stock Market. Public Opinion Quarterly, 15(3), 461-486.

Salehi, M. Ghabezi, R. Mousavi Shiri, S M. Bordbar, E,. (2015). Analysis of the 
effect of payment of cash subsidy on stock price and creation of abnormal return in oil products industry. Quarterly of energy economy studies, 11(46), 89-112.

Salehi, M. Mousavi Shiri, S Ma. Ibrahimi Soveiyzi, M,. (2014). Informative content of declared and predicted profit per share in the expression of abnormal stock return. Quarterly of financial accounting and auditing studies, 6(21), 117-140.

Wang, J. Xin, R. Tan, J. Zhao, W. Li, Q,. (2017). Rumor Clarification, Digital Platform, and Stock Movement. Proceedings of the Pre-ICIS 2017 SIGDSA Symposium.

Yao, H. xing, Liu, D,. (2019) Study on Stock Market Rumor Spread Model with Medium. International Journal of Scientific Engineering and Science,3(3), 47-53.

Zhang, N., and Liu, C. L. (2012). "The Role of Corporate Reputation and Media Authority in Rumor Clarification-An Empirical Study on Coping with the Security Market Rumor. Journal of Business Economics, (6), pp. 11.

Zhao, J. M., He, X., and Wu, F. Y. (2010). Study on Chinese stock market rumors and the impact on stock prices, Management World, (11), 38-51.

Bibliographic information of this paper for citing:

Hatam, Javid; Bokharaeian Khorasani, Maryam; Naderian, Arash \& Gorganli Doji, Jamadori (2021). The Event Research in the Effect of Clear Rumor Declarations on Abnormal Stock Returns Behavior. Iranian Journal of Finance, 5(3), 17-37.

Copyright ( 2021, Javid Hatam, Maryam Bokharaeian Khorasani, Arash Naderian and Jamadori Gorganli Doji 